\title{
Does COMESA Have Export Potential to Emerging Economies?
}

\author{
Lucia Mary Mbithi \\ School of Economics, University of Nairobi, Kenya
}

\begin{abstract}
By the virtue of their size, Emerging Market Economies (EMEs) present trade opportunities for both developed and developing countries. To benefit from such opportunities, countries need to identify the areas where they have comparative advantage. This paper analyses the export potential of the Common Market for Eastern and Southern Africa (COMESA) member countries to selected emerging market economies (EMEs) including Brazil, Russia, India, China, Turkey, Singapore, Saudi Arabia, United Arab Emirates (UAE), South Africa and Nigeria. The aim is to investigate if COMESA member countries are competitive in the EMEs and identify the specific products which the region has a revealed comparative advantage (RCA) in specific EME market. Using RCA method, the study finds that COMESA countries have RCA in at least 200 products (about 4 percent) of the total 5,134 products they export to the selected emerging markets. Export of these products also account for a small market share in the emerging markets. COMESA countries therefore have a large export potential in these markets which remains unexploited. Export potential is larger in Russia, Nigeria, Saudi Arabia and UAE, respectively. Textiles and textile products, mineral products, base metal and articles of base metal, live animals and vegetable products have the largest export potential in EMEs.
\end{abstract}

Keywords: COMESA, emerging market economies (EMEs), RCA and export potential

DOI: $10.7176 / \mathrm{JESD} / 11-10-07$

Publication date:May $31^{\text {st }} 2020$

\section{Introduction}

Emerging economies present export market opportunities for COMESA member countries. An emerging market economy (EME) has been defined as a country characterised by good growth prospects, high rates of investment returns but also with a high level of risk and hence high volatility, absence of a history of foreign investment, and in the process of transitioning into a more developed market economy (Mody, 2004). Emerging economies include lower-middle to upper middle-income countries, as based on World Bank classification of national income, they have a Gross National Income (GNI) per capita of between \$1,026 and \$12, 375 .

Ten (10) emerging economies including: Brazil, Russia, India, China, Turkey, Singapore, Saudi Arabia, United Arab Emirates (UAE), South Africa and Nigeria are selected based on economic indicators of Gross Domestic Product (GDP) and its growth rate, population and it's growth rate, and on size and growth of exports and imports of goods and services. Based on the World Bank Development Indicators Database (World Bank 2017), these countries' population represents about two-thirds of the world population; their GDP about a third of the world's, and goods and services account for over a quarter of the world's trade. Furthermore, the annual growth rates of these countries' population, GDP, GDP per capita, exports and imports of goods and services has been way above the World's average over. Given the large size of their economies (in terms of population and GDP), high growth rates, sound public finances and trade openness, these countries present potential trade and investment opportunities, not only to the developed countries but also to other developing and least developed countries.

The aim of this paper is to investigate if COMESA has potential to export to the EMEs and identify the specific products which the region has a revealed comparative advantage in each specific EME. The study adds to the existing literature on the potential for COMESA member countries' exports to emerging economies, information which is useful to policy makers and researchers in COMESA region.

This paper is organized follows: after this introduction, section 2 discusses trade between COMESA and emerging economies, tariff market access conditions in those economies for COMESA exports and reviews literature on COMESA countries revealed comparative advantage. Section 3 discusses the methodology used in the study, section 4 presents and discusses the results while section 5 concludes.

\section{COMESA trade with emerging markets}

\subsection{Trade}

Over the period 2006-2015, COMESA exports globally and to the EMEs increased though with fluctuations. On a yearly basis, global COMESA exports increased from 63 US\$B to over 77 US\$B while exports to the ten selected EMEs increased three-fold from about 9 US\$B to over 27 US\$B. The trend in COMEA exports globally and to the EMEs in particular is shown in Figure 1. 


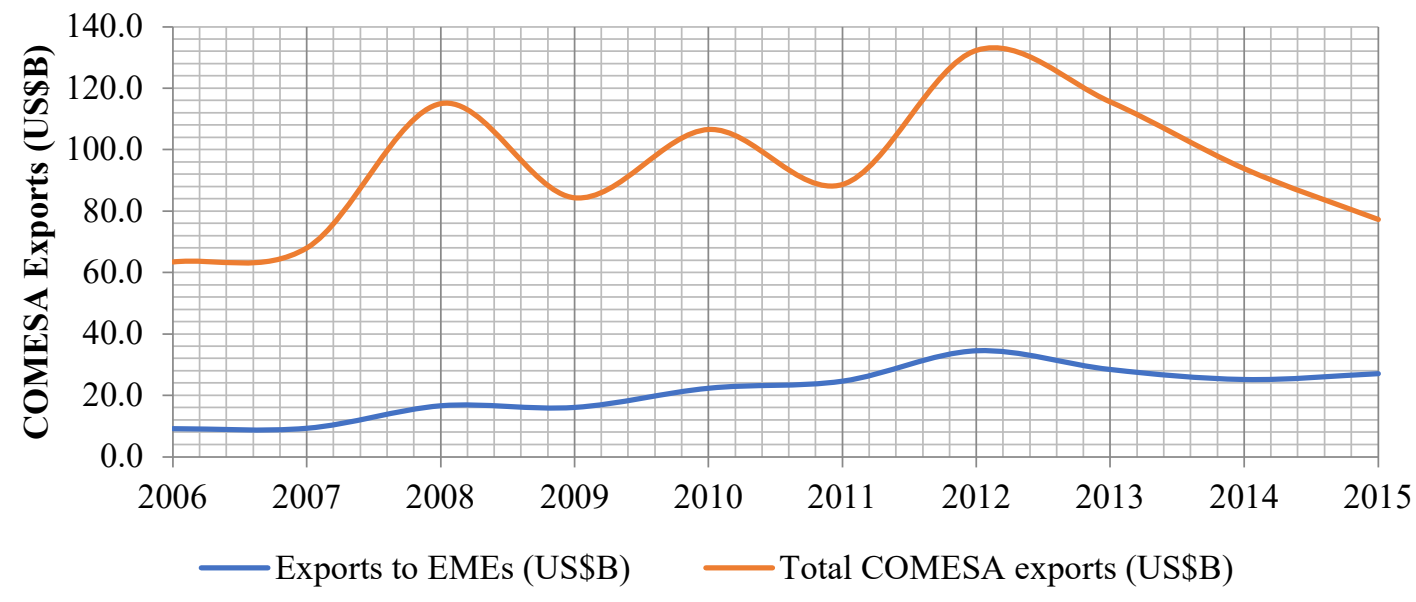

Source: Comtrade database

Figure 1: Trends in COMESA exports (2006-2015)

Emerging economies are key trading partners for COMESA in terms of both size and the number of products traded. On average, COMESA exports to the EMEs were about 22 percent of the region's global exports over this time, although this share has been increasing lately, standing at about 35 percent in 2015 . Table 1 shows the top 10 trading partners for COMESA for the period 2011-2015.

Table 1: Top 10 trading partners for COMESA (2011-2015)

\begin{tabular}{|c|c|c|c|c|c|}
\hline \multicolumn{3}{|c|}{ Export markets } & \multicolumn{3}{|c|}{ Import markets } \\
\hline Partner & Value (US\$B)/ year & $\begin{array}{l}\text { Market } \\
\text { Share (\%) }\end{array}$ & Partner & Value US\$B/ year & $\begin{array}{l}\text { Market } \\
\text { Share (\%) }\end{array}$ \\
\hline Italy & 12.4 & 11.6 & China & 25.6 & 14.2 \\
\hline China & 10.6 & 9.8 & India & 12.1 & 6.7 \\
\hline Germany & 5.7 & 5.4 & South Africa & 11.6 & 6.4 \\
\hline France & 5.6 & 5.2 & USA & 8.8 & 4.9 \\
\hline Switzerland & 5.5 & 5.1 & Germany & 7.6 & 4.2 \\
\hline South Africa & 5.1 & 4.8 & Italy & 7.4 & 4.1 \\
\hline UAE & 4.6 & 4.3 & UAE & 7.0 & 3.9 \\
\hline USA & 4.3 & 4.0 & Turkey & 6.2 & 3.4 \\
\hline UK & 3.7 & 3.5 & Saudi Arabia & 5.5 & 3.1 \\
\hline Saudi Arabia & 3.5 & 3.3 & France & 4.7 & 2.6 \\
\hline Total top 10 & 61.1 & 57.0 & Top 10 markets & 96.5 & 53.6 \\
\hline
\end{tabular}

Source: COMTRADE

For the period 2011-2015, China was the second largest export market and the largest import market for COMESA member countries, while South Africa and UAE were among the top 10 export destination markets. For import markets, India, South Africa, UAE, Turkey and Saudi Arabia were among the top ten. Both the global export and import markets for COMESA are relatively concentrated, with the top 10 markets accounting for over 50 percent of the market share. Table 2 shows some indicators of COMESA exports to EMEs.

Table 2: Selected COMESA export indicators to the EMEs (2006-2015)

\begin{tabular}{|l|l|l|l|}
\hline COMESA member state & Trade Value (US\$B) & No. of products exported & $\begin{array}{l}\text { Av. Annual Growth } \\
\text { of Trade (\%) }\end{array}$ \\
\hline Brazil & 0.6 & 635 & 1.2 \\
\hline China & 4.2 & 2,204 & 1.2 \\
\hline India & 3.3 & 2,065 & 1.1 \\
\hline Nigeria & 0.2 & 1,730 & 1.3 \\
\hline Russia & 0.6 & 739 & 1.2 \\
\hline Saudi Arabia & 2.8 & 2,538 & 1.2 \\
\hline Singapore & 0.3 & 1,156 & 1.1 \\
\hline South Africa & 1.8 & 3,690 & 1.1 \\
\hline Turkey & 1.8 & 1,929 & 1 \\
\hline UAE & 2.2 & 2,565 & 5.7 \\
\hline
\end{tabular}

Source: COMTRADE 
On average exports by COMESA to each of the EME grew at a rate of at least 1 percent per annum. During the same period, the number of products COMESA exported globally increased from 4512 to 5537 product lines while those exported to the ten EMEs increased from 2685 to 3311 product lines.

In terms of the number of products, South Africa, UAE and Saudi Arabia are among the top ten export destination markets, while South Africa, China and India are among the top 10 import source markets. For the period 2011-2015, COMESA region was a net importer, with import value being about 2.5 times the regions' export value to these markets. On average, COMESA exported products of a value of about US\$B 31 and imported products of a value of about US\$B 77 from these markets on annual basis over the same period. Exports consisted of 4,337 tariffs lines while imports were 4,942 tariff lines.

Exports by COMESA member countries to EMEs are relatively concentrated, with the top 10 most exported products accounting for about 56 percent of COMESA exports to the EMEs, and petroleum oils and metals accounting for 51 percent of this proportion. A part from one product (oils; petroleum oils and oils obtained from bituminous minerals, not crude; preparations), all the top 10 export products are raw, unprocessed products. The most imported products from these markets are manufactured goods except for wheat, meat and Sucrose, which through agriculturally derived products are high value products.

\subsection{Trade relations between COMESA and the Emerging markets}

Majority of EMEs have some form of trading relation at the Africa level or at bilateral or at multilateral level with one or more of COMESA Member States. At the Africa level, China, India and Turkey have trade relations with COMESA Member countries.

Cooperation under the Forum on China-Africa Cooperation (FOCAC) is virtually in all areas including in political, international affairs, economics, trade, financial, investment, resources, energy, marine economy and development. The Africa-Turkey Partnership aims at achieving a long-term cooperation in the spaces of economic (trade), development, health, security and culture while Africa-India economic cooperation aims at promoting inclusive and sustainable growth for a decent life for the parties' peoples. Other regional trading arrangements (RTAs) between COMESA member states and EME are summarized in Table 3.

Table 3: Trading arrangements between COMESA countries and EMEs

\begin{tabular}{|l|l|l|l|l|}
\hline RTA Name & COMESA member state & Coverage & Type & $\begin{array}{l}\text { Date of entry } \\
\text { into force }\end{array}$ \\
\hline Egypt - Turkey & Egypt SADC EPA & $\begin{array}{l}\text { DRC, Madagascar, Malawi, } \\
\text { Mauritius, Seychelles, Swaziland, Goods } \\
\text { Zambia and Zimbabwe }\end{array}$ & FTA & 10-Oct-16 \\
\hline $\begin{array}{l}\text { Southern African Customs } \\
\text { Union (SACU) }\end{array}$ & Swaziland & Goods & CU & 910 \\
\hline $\begin{array}{l}\text { Southern African Development } \\
\text { Community (SADC) }\end{array}$ & $\begin{array}{l}\text { DRC, Mauritius, Seychelles, Swaziland, Goods } \\
\text { Zambia and Zimbabwe }\end{array}$ & FTA & $1-$ Sep-00 \\
\hline $\begin{array}{l}\text { Turkey - Mauritius } \\
\text { Global System of Trade } \\
\text { Preferences among Developing } \\
\text { Countries (GSTP) - (Egypt, } \\
\text { Libya, Sudan and Zimbabwe) }\end{array}$ & $\begin{array}{l}\text { Brazil, India, Nigeria and } \\
\text { Singapore }\end{array}$ & Goods & FTA & 1 -Jun-13 \\
\hline
\end{tabular}

Source: WTO RTA and PTA data base, Accessed September 2017

The China LDC Scheme is a full duty-free treatment to LDCs covering on HS eight-digit basis up to 8,036 out of 8,285 tariff lines contained in China's 2015 import tariff schedule, or 97 percent of China's total import tariff lines (UNCTAD, 2016). This Scheme has been implemented in 3 phases: Phase 1 in 2010: duty-free treatment to LDCs applied to 60 percent of China's import tariff lines (that is, 4,762 out of 7,936 tariff lines); Phase 2 in 2013: duty-free was extended to cover 95 percent of China's total tariff lines, or 7,381 out of 8,243; and phase 3: 2015, duty-free coverage extended to 97 percent of China's total import tariff lines. COMESA member states benefiting from the scheme are Burundi, DRC, Djibouti, Ethiopia, Madagascar, Malawi, Sudan and Uganda.

Product coverage includes poultry and other livestock, aquatic products, raw or primary processed agricultural products, minerals, herbs, daily necessities, plastic products, leather, wood, textiles (including cotton yarn), clothing, glass and steel and their products, machinery and electrical products, furniture, automobiles and other motor vehicles.

Excluded tariff lines include automobile, paper and timber products. Products subject to global tariff rate quotas constituting some 47 tariff lines including chemical fertilizers, corn, raw cotton, rice, sugar, wheat, wool 
and wool fibre, are also excluded from the LDC Scheme. In-quota duties range from 1 to 15 percent, while outof-quota most-favoured nation duties range from 38 to 65 percent. COMESA LDCs exporting to China under the second phase preferences (duty free for $95 \%$ of China import tariff lines) as they await exchange of letters include: Comoros, Eritrea, Rwanda, and Zambia. To benefit from the Scheme, products covered need to meet the rules of origin.

The India Duty Free Tariff Preference (DFTP) for the LDCs provides preferential tariff market access to India for products originating from the notified Least Developed Countries. The scheme provides duty free or preferential market access on about $98.2 \%$ of India's tariff lines (at HS 6 digit level of classification), with over 85 percent of the tariff lines including cut flowers, leguminous vegetables, dates, some fruits \& spices, vegetable oils, dyes \& chemicals, plastic materials, apparel \& clothing being on duty free basis. Other products are on reduced duty basis with reductions ranging from 10 to 90 percent of the MFN. $1.8 \%$ of the tariff lines have been excluded from the preferences under the Scheme (WTO, 2015). The excluded products include: poultry, milk \& cream; vegetables like potatoes, tomatoes, onions etc., coconut, coffee, tea, beverages, spirits and some products of iron and steel products. 31 LDCs are beneficiaries of this scheme, the COMESA ones being: Burundi, Comoros, Eritrea, Ethiopia, Madagascar, Malawi, Rwanda, Sudan, Uganda and Zambia. COMESA LDCs not participating in the scheme are DRC and Djibouti (Department of Commerce- India, 2015).

Russian Federation Generalized System of Preferences provides developing countries with $25 \%$ tariff reduction from MFN for some 2,800 products (10-digit levels of HS Code) or 24 percent of tariff lines of the Eurasian Customs Union for both agricultural and industrial products. For LDCs, these products enter Russia on duty free as a part of a special duty-free scheme for LDCs (WTO, 2013). The agricultural products covered under the scheme are: chapter 02 (meat), chapter 15 (oils and animal, chapter 16 (foods) and chapter 20 (vegetable and fruit productions). Industrial products include: chapter 25 (salt), chapter 33 (cosmetics), chapter 40 (rubber), chapter 44 (wood) and chapter 94 (furniture). COMESA member countries are eligible to benefit from the Scheme either as developing countries or as LDCs.

2.3 COMESA exports market access conditions in emerging markets

The general market access conditions for COMESA products in the EMEs is mainly on MFN basis, although tariffs are relatively low (Table 4).

Table 4: COMESA market access conditions in Emerging Economies (2011- 2015)

\begin{tabular}{|l|l|l|l|l|l|l|l|}
\hline Country & $\begin{array}{l}\text { Applied Tariff } \\
\text { (W. Av. \%) }\end{array}$ & $\begin{array}{l}\text { Number of } \\
\text { Total Lines }\end{array}$ & $\begin{array}{l}\text { Imports } \\
\text { Value (\$M) }\end{array}$ & $\begin{array}{l}\text { Dutiable } \\
(\%)\end{array}$ & $\begin{array}{l}\text { MFN } \\
\text { imports }(\%)\end{array}$ & $\begin{array}{l}\text { Preferential } \\
(\%)\end{array}$ & $\begin{array}{l}\text { MFN } \\
\text { imports }(\%)\end{array}$ \\
\hline Nigeria & 13.7 & 11.4 & 106.3 & 95.3 & 100 & 0 & 4.7 \\
\hline Brazil & 13.3 & 20.8 & 208.8 & 78.8 & 90.2 & 9.8 & 21.2 \\
\hline India & 12.5 & 65.7 & 2114 & 65.9 & 74.4 & 25.6 & 34.1 \\
\hline China & 8.3 & 62.2 & 4128.1 & 42.7 & 50 & 50 & 28.5 \\
\hline Turkey & 7.9 & 72.3 & 1596.1 & 90.6 & 9.4 & 49.5 & 9.4 \\
\hline Russia & 6.8 & 6.8 & 2301.3 & 94.1 & 41.3 & 58.7 & 5.9 \\
\hline UAE & 4.6 & 35.9 & 1883.6 & 29.5 & 72.4 & 27.6 & 41.1 \\
\hline S Africa & 3.5 & 106.4 & 3908.2 & 69.4 & 61.6 & 38.4 & 30.6 \\
\hline $\begin{array}{l}\text { Saudi } \\
\text { Arabia }\end{array}$ & 2.8 & 20.6 & 4.9 & 88.5 & 68.9 & 37.5 & 17.8 \\
\hline Singapore & 0 & 41.8 & 387.8 & 0 & 100 & 0 & 100 \\
\hline
\end{tabular}

Source: UNTRAINS

The highest average tariffs of 13.7 and 13.3 percent are applied in Nigeria and Brazil markets respectively, while the lowest tariffs are encountered in Singapore and Saudi Arabia ( 0 and 2.8 percent respectively). Preferential market access is largest in Russia and China (accounting for 59 of exported products in both cases).

Excluding Nigeria and Singapore which do not provide trade preferences to COMESA member countries, there is clear under-utilization of the current preferences as a small proportion of exports enters these markets on MFN basis. Tariffs applied on various COMESA product categories exported to each EMEs markets is shown in Table 5. 
Table 5: Tariffs applicable to various COMESA products exported to EME

\begin{tabular}{|c|c|c|c|c|c|c|c|c|c|}
\hline \multirow[b]{2}{*}{ Country } & \multicolumn{3}{|c|}{ Agricultural } & \multicolumn{3}{|c|}{ Manufacturing } & \multicolumn{3}{|c|}{ Petroleum fuels } \\
\hline & $\begin{array}{l}\text { W. Av. } \\
\text { Tariff } \\
(\%)\end{array}$ & $\begin{array}{l}\text { \%o } \\
\text { MFN } \\
\text { imports }\end{array}$ & $\begin{array}{l}\text { Free } \\
\text { MFN }\end{array}$ & $\begin{array}{l}\text { W. Av } \\
\text { Tariff } \\
(\%)\end{array}$ & $\begin{array}{l}\% \quad \text { MFN } \\
\text { imports }\end{array}$ & $\begin{array}{l}\text { Free } \\
\text { MFN }\end{array}$ & $\begin{array}{l}\text { W. Av } \\
\text { Tariff } \\
(\%)\end{array}$ & $\begin{array}{l}\% \text { MFN } \\
\text { imports }\end{array}$ & $\begin{array}{l}\text { Free } \\
\text { MFN }\end{array}$ \\
\hline Brazil & 10.0 & 100.0 & 88.0 & 7.4 & 100.0 & 4.4 & 2.2 & 100.0 & 0.0 \\
\hline China & 7.0 & 76.0 & 0.1 & 0.58 & 95.4 & 74.1 & 0.0 & 100.0 & 100.0 \\
\hline India & 12.5 & 63.3 & 7.6 & 2.7 & 62.8 & 0.2 & 0.5 & 100 & 89.8 \\
\hline Nigeria & 19.2 & 100.0 & 0.0 & 11.2 & 99.9 & 0.1 & - & - & - \\
\hline Russia & 6.1 & 19.6 & 19.6 & 6.6 & 9.7 & 3.1 & 5.0 & 100.0 & 0.0 \\
\hline S. Arabia & 2.6 & 100 & 56.8 & 5.4 & 100.0 & 6.2 & 5.4 & 100.0 & 0.0 \\
\hline Singapore & 0.0 & 100.0 & 100.0 & 0.0 & 100.0 & 100.0 & 0.0 & 100.0 & 100.0 \\
\hline S. Africa & 0.8 & 58.0 & 9.3 & 3.0 & 40.2 & 40.2 & 0.5 & 52.4 & 52.8 \\
\hline Turkey & 24.2 & 93.8 & 12.1 & 0.25 & 57.1 & 13.1 & 0 & 100 & 0 \\
\hline UAE & 0.8 & 79.4 & 31.7 & 1.9 & 84.3 & 40.2 & 0.1 & 50.6 & 0.0 \\
\hline
\end{tabular}

Source: TRAINS database

Agricultural exports face the highest tariffs, with the highest average tariffs of 24 and $19 \%$ being encountered in Turkey and Nigeria respectively. Lowest tariffs for agricultural products are encountered in Singapore and in UAE.

\subsection{Recent studies on COMESA export potential}

Several studies have analyzed RCA for COMESA, with most of them analyzing RCA for intra-regional trade. Skate (2016) analyzed the RCA for common agricultural commodities in the COMESA region and also identified commodities that COMESA member countries could focus on for their agro-food industries development. His findings showed that only a few countries in the region exhibit strong RCA in highly processed food commodities, hence concluding that there is still a large scope for agro-processing based on the region's abundant raw materials.

A study by Guthinga, et al., (2019), analyzing trade competitiveness of selected agricultural commodities traded among COMESA countries using the revealed comparative advantage (RCA) methodology showed that different COMESA member countries have had fluctuating advantages in trade in different food staples over the years due to changes in weather. The study also shows competitive export products for various countries such as bovine live animals and meat, cassava, maize grain, tomatoes, fish, wheat flour, onions and dry legumes and pulses.

A study by Katende and Kuteesa (2016) analyzed the competitiveness and stability of Uganda's RCA in COMESA and found that Uganda has RCA in all 16 industries at the product chapter level, with stable RCA in exports of animals, vegetables, food production, wood, textiles, \& cloth, stone \& glass and metals. A related study by Chingarande, Mzumara and Karambakuwa (2013) for East African Community (EAC) Partner States found that, EAC countries have comparative advantage in several product lines with Kenya having comparative advantage in 471 product, while Tanzania has in 471 products, Uganda has in 437 product, Rwanda in 275 products and Burundi in 152 products.

A study by Yego, Samoei and Biwott (2016) using RCA methodology to establish competitiveness of Kenyan tea exports to Russian, Egyptian and Pakistan shows that Kenya has a strong comparative advantage in tea exports over her main rivals in the international market.

\section{Methodology and data}

Using data for the period 2011- 2015, we analyze the RCA of COMESA member states and identify products with export potential to the emerging markets and to the specific emerging market economy. Estimation of the RCA was undertaken using the 5-year average trade value for each of the 5,134 product lines exported globally by the COMESA member states during the study period.

The Concept of RCA is the Ricardian theory of comparative advantage (Ricardo, 1817), which posits that the main motivation of international trade is difference in technology. A country is assumed to have a comparative advantage in the production of a good if it can produce that good at a lower opportunity cost than another country. Balassa (1965) further developed the measurement of RCA, following with the approach which is commonly known as the Balassa Index, which has been widely used to measure a country's exports of a commodity or industry relative to its total exports and to the corresponding exports of a set of countries. RCA of a country is expressed in equation 1 :

$\mathrm{RCA}=\left(\mathrm{X}_{i j} / \mathrm{Xit}\right) /\left(\mathrm{X}_{n j} / \mathrm{X}_{n t}\right)=\left(\mathrm{X}_{i j} / \mathrm{X}_{n j}\right) /\left(\mathrm{X}_{i t} / \mathrm{X}_{n t}\right) \ldots \ldots \ldots$. equation 1

Where, $\mathrm{X}$ represents exports, $i$ is a country, $j$ is a commodity (or industry), $t$ is a set of commodities (or industries) and $n$ is a set of countries.

A country has a revealed comparative advantage if estimates of RCA $>1$. If RCA is less than unity, the country is 
said to have a comparative disadvantage (RCD) in the commodity or industry analyzed.

In this analysis we estimate the RCA and RCD as shown in equations 2 and 3.

$\mathrm{RCA}=\frac{X_{i}^{k} / X^{k}}{X_{i}^{w} / X^{w}}$ equation 2

where, $X$ is the value of exports, $k$ is exporting country, $w$ is the World, and $i$ is the exported product.

Revealed comparative disadvantage (RCD) is estimated as:

$(\mathrm{RCD})=\frac{M_{i}^{p} / M^{p}}{M_{i}^{w} / M^{w}} \ldots \ldots \ldots \ldots \ldots \ldots \ldots \ldots \ldots$ equation 3

where, $M$ is the value of imports, $p$ is the importing country, $w$ is the World, and, $i$ is the imported product.

Products with export potential for each COMESA member state in the EMEs were selected using the following two criteria: RCA of COMESA MS > 1, and RCD of EME $>1$.

Data used in this study was obtained from UNCOMTRADE and UNTRAINS databases and comprised of value of exports of each member country for the period 2011-2015. Products classification was based on the Harmonized Commodity Description and Coding System (HS96).

\section{Results and discussion}

In total 220 relationships were analyzed including 19 COMESA Member states and 10 EMEs; 19 COMESA member states and EMEs region (19); and COMESA region and 10 EM (10); and COMESA region and the EMEs region.

The analysis shows that the combined COMESA region has RCAs in 200 products (about 4 percent) of the total 5,134 products they exported to the ten EMEs over the period 2011-2015. The Number of products for each COMESA member state with export potential in each EME are summarized in Annex 1.

The categories of products with export potential to EMEs include: textiles and textile products, mineral products, base metal and articles of base metal, live animals and vegetable products. Export of these products account for varying market shares in the EMEs, with 12 percent of them having a market share of at least 10 percent, 7 percent have a market share greater than 20 percent, and 3 percent of them with a market share of over 50 percent. 88 percent of the COMESA products with RCA to the EMEs market have a market share of less than 10 percent, with 63 percent of all products with RCA having a market share of less than 1 percent these markets.

The limited market share of COMESA exports for products with export potential suggests that these products have a large export potential in the EMEs markets which remains unexploited. A summary of the number of COMESA products with export potential in EMEs and their respective market shares in those markets are shown in Table 6.

Based on the number of products with export potential and the market shares of exports in the various export markets, it is estimated that the largest export potential in terms of the number of products is in Russia, Nigeria, Saudi Arabia and UAE, respectively.

Products with export potential in Brazil are mainly non-agricultural products. COMESA export of these products is limited, with only 6 products commanding a market share of over 10 percent. COMESA member states have 125 products with an export potential to China including agriculture, minerals and light manufactured products such as textiles and leather. Export of these products is however low as only a few of them command a market share of over 10 percent. Cobalt and oil cake command highest market shares in of 93 and 74 respectively in the China market.

With respect to the Indian market, COMESA has about 170 products with export potential, which are mainly agricultural and mineral products. The most exported products include clove seeds and refined copper, accounting for 95 and 75 percent of market shares respectively.

For Nigeria market, COMESA has RCA in 141 products. This includes a mix of agriculture, minerals, light manufactures such as paper and plastics, and chemical products. COMESA member states' exports of these products remain low as the market share for majority of these products is below 10 percent and 34 percent of these products have a negligible market share. 
Table 6: Number of COMESA products with RCA and market shares in EMEs

\begin{tabular}{|l|l|l|l|l|l|l|}
\hline \multirow{2}{*}{ EME } & \multirow{2}{*}{ No. of products with Export potential } & \multicolumn{3}{|c|}{ Number pod products with market share (\%) } \\
\cline { 3 - 7 } & & Over 50 & $\mathbf{2 0}$ to 50 & $\mathbf{1 1}$ to 20 & $\mathbf{1 0}$ to 1 & Below 1 \\
\hline Brazil & 163 & 3 & 0 & 2 & 13 & 145 \\
\hline China & 125 & 9 & 4 & 5 & 27 & 80 \\
\hline India & 170 & 3 & 4 & 8 & 37 & 118 \\
\hline Nigeria & 251 & 3 & 5 & 8 & 33 & 202 \\
\hline Russia & 233 & 0 & 6 & 5 & 17 & 205 \\
\hline Saudi Arabia & 332 & 17 & 24 & 30 & 81 & 180 \\
\hline Singapore & 129 & 1 & 0 & 1 & 4 & 123 \\
\hline South Africa & 261 & 32 & 24 & 20 & 60 & 125 \\
\hline Turkey & 192 & 7 & 14 & 14 & 38 & 119 \\
\hline UAE & 219 & 5 & 10 & 15 & 34 & 155 \\
\hline
\end{tabular}

For Russia, COMESA has RCA for 107 products with the bulk of these products being agricultural and related products, accompanied by a few minerals and a few light manufactures including textiles and other products. Export of these products is limited as evidenced by negligible market shares of most of products with RCA in the Russia market.

For Saudi Arabia market, 324 products show export potential for COMESA. This is relatively a more diversified mix of products including agricultural products, live animals, meat and light manufactured products. Exports of about 20 percent of these products command a significant market share of over 20 percent. Products with RCA and the largest export shares in Saudi Arabia are mainly vegetables and fruits.

128 products from COMESA region have potential for export to the Singapore market. These consist of a mix of agricultural products (vegetables, flowers and nuts), textiles, minerals and a few manufactured products including paper, paper board, cells and batteries. Spices, hides and skins have the highest market share in Singapore, accounting to 70 and 17 percent of the market shares respectively. It is also observed that 22 percent of COMESA products with RCA in Singapore market have an insignificant market share.

260 COMESA export products have potential for export to South Africa. These are a mix of minerals, relatively a few agricultural products (vegetables, spices, tobacco, rice, black tea, fruits) cotton yarn, textiles, wood, paper, paperboard and other light manufactured products including washing preparations, plastics, cement and aluminum bars, among other products. 12 percent of these products have an impressive export shares in South Africa of over 50 percent and 17 percent have a market share of between 10 and 50 percent. 48 percent of the products showing RCA to South Africa have negligible market share.

189 products show RCA in the Turkey market. These comprise of a mix of Cotton yarn, agricultural products and manufactured products including glass among others. 5 products, related to Cotton yarn, sand and live fish have a market share of over 50 percent while 12 percent of these products have a negligible market share. 219 products show RCA in the UAE market. These consist of agricultural, minerals, textiles and fabrics, glass, cells, batteries and ceramics. Goat meat, black tea, spices, copper and diamonds, each has a market share of over 50 percent. 38 percent of product with export potential comprising of mainly manufactured products have a negligible market share.

\section{Conclusions and recommendations}

The analysis shows that COMESA member states have RCA in at least 200 products (about 4 percent) of the total 5,134 product lines they export to the ten EMEs. The limited market share of COMESA exports of products with RCA in these markets suggests that these products have a large export potential in the EMEs, which remains unexploited. COMESA member states therefore have a large export potential in the emerging markets.

Based on the number of products with RCA and market shares of these products in various EME markets, it is estimated that the larger export potential in terms of the number of products are in Russia, Nigeria, Saudi Arabia and UAE. Egypt, Kenya, Mauritius, Swaziland and Uganda have relatively more products with export potential in most of the markets as compared to other COMESA Member States. Russia, Nigeria and UAE present the largest potential export markets.

Textiles and textile products, mineral products, base metal and articles of base metal, live animals and vegetable products have the largest export potential in EMEs. Export of these products command varying market shares in the EMEs, ad 88 percent of them have market shares of less than 10 percent.

Based on the findings and conclusions of this study, it is important for COMESA Member states to develop strategies to overcome existing obstacles to trade with the emerging economies, therefore better exploiting the export opportunities in these markets with respect to products for which they have RCA.

This study did not analyze the specific challenges hindering exports to EMEs of COMESA products with export potential. It is therefore recommended that further research is needed to identify these challenges and hence 
inform the strategies which COMESA can use to advance exports to EMEs.

\section{References}

UNCTAD (2016). Handbook on the special and preferential tariff scheme of china for least developed countries. United Nations. New York and Geneva.

Department of Commerce- India (2015). India Duty Free Tariff Preference (DFTP) for the Least Developed Countries. [online] Available: https://commerce.gov.in/writereaddata/pdf_download/DFTP.pdf

UNCTAD (1993). Generalized system of Preferences. Scheme for Russia Federation. UNCTAD.

WTO (2013). Notification of Preferential Trade Arrangement: Russia Federation. WT/COMTD/N/42. WTO, Geneva.

WTO (2015). Duty Free Least Developed Tariff Preference Scheme of India for Countries. G/C/W/651/Add.1 and WT/COMTD/N/38/Add.1. WTO.

Mody, A. (2004). What Is an Emerging Market? IMF Working Paper, WP/04/177.

Balassa, B. (1965): Trade liberalization and revealed comparative advantage. Minch. Sch. Econ. Soc., 33, 99-123

Chingarande, A., Mzumara, M., \& Karambakuwa, R. (2013). Comparative Advantage and Economic Performance of East African Community (EAC) Member States, Journal of Economics, 4:1, 39-46.

Katunze, M. and Kuteesa, A. (2016). Uganda's Revealed Comparative Advantage in COMESA. Journal of Sustainable Development; Vol. 9, No. 3; 192-207.

Guthiga, P., Ogade, M., Karugia, J., Ongudi, S., and Mugweru. L. (2019). Trade Competitiveness Among COMESA Countries in Agricultural Commodity Exports. ReSAKSS Working Paper No. 41. International Food Policy Research Institute (IFPRI)

Ricardo, D (1817). On the Principles of Political Economy and Taxation. In: Works of David Ricardo, Vol. 1, ed. by Pierro Sraffa with the collaboration of M. H. Dobb, Cambridge: Cambridge University Press, 1951. [online] Availble: https://www.econlib.org/library/Ricardo/ricP.html?chapter_num=2\#book-reader

Yego, H., Samoei, K. S. and Biwott, K. D. (2016). Revealed Comparative Ādvantage and Competitiveness: A case of Kenyan Tea Exports to the International, Russian, Egypt and Pakistan Markets. ResearchJournalis Journal of Economics. Vol. 4, No. 2.

World Bank (2017). Development Indicators Database. http://datatopics.worldbank.org/world-developmentindicators/, accessed April 2020.

Annex 1: Number products with export potential in EMEs for Each COMESA Member State

\begin{tabular}{|c|c|c|c|c|c|c|c|c|c|c|c|c|c|c|c|c|c|c|c|c|}
\hline \multirow{2}{*}{ Economy } & \multicolumn{20}{|c|}{ COMESA Member State } \\
\hline & $\begin{array}{l}\text { All } \\
\text { COMESA }\end{array}$ & BUR & $\mathrm{COM}$ & DJI & DRC & EGY & ERI & ETH & KEN & LIB & MAD & MAL & MAU & RWA & SEY & SUD & SWA & UGA & ZAM & ZIM \\
\hline All EME & 200 & 45 & 17 & 72 & 30 & 151 & 32 & 69 & 129 & 18 & 93 & 70 & 125 & 68 & 23 & 37 & 135 & 123 & 64 & 58 \\
\hline Brazil & 163 & 40 & 16 & 32 & 17 & 169 & 9 & 47 & 120 & 7 & 79 & 55 & 96 & 73 & 21 & 9 & 155 & 117 & 70 & 36 \\
\hline China & 126 & 29 & 3 & 49 & 24 & 83 & 23 & 41 & 77 & 10 & 81 & 28 & 90 & 40 & 13 & 29 & 73 & 65 & 41 & 44 \\
\hline India & 170 & 35 & 14 & 54 & 26 & 134 & 22 & 38 & 115 & 21 & 60 & 60 & 92 & 47 & 12 & 20 & 127 & 84 & 57 & 45 \\
\hline Nigeria & 251 & 68 & 26 & 55 & 27 & 243 & 11 & 56 & 217 & 7 & 80 & 115 & 123 & 134 & 32 & 18 & 160 & 236 & 104 & 85 \\
\hline Russia & 234 & 69 & 23 & 57 & 24 & 255 & 15 & 86 & 208 & 3 & 134 & 101 & 147 & 120 & 25 & 14 & 168 & 195 & 100 & 68 \\
\hline Saudi Arabia & 325 & 77 & 35 & 74 & 22 & 329 & 16 & 127 & 243 & 8 & 139 & 144 & 199 & 146 & 38 & 40 & 176 & 262 & 120 & 91 \\
\hline Singapore & 129 & 33 & 18 & 24 & 14 & 117 & 8 & 46 & 87 & 7 & 72 & 66 & 118 & 69 & 25 & 13 & 90 & 122 & 60 & 34 \\
\hline South Africa & 261 & 61 & 21 & 62 & 30 & 233 & 17 & 95 & 209 & 8 & 140 & 113 & 198 & 120 & 33 & 30 & 194 & 214 & 116 & 101 \\
\hline Turkey & 193 & 47 & 15 & 56 & 15 & 210 & 19 & 50 & 110 & 14 & 74 & 72 & 105 & 71 & 16 & 28 & 123 & 118 & 63 & 55 \\
\hline UAE & 220 & 51 & 26 & 55 & 21 & 227 & 16 & 97 & 148 & 6 & 129 & 91 & 168 & 99 & 28 & 29 & 109 & 173 & 80 & 74 \\
\hline
\end{tabular}

